Рекомендована д. фрармац. наук, профр. Л. Л. Давтян

УДК 615.014.24:542.64

\title{
РОЗРОБКА МЕТОДИК КОНТРОЛЮ ДЛЯ ЛАБОРАТОРНОЇ ТЕХНОЛОГІї ГЛЮКОЗОВМІСНИХ ПЕРИТОНЕАЛЬНИХ ДІАЛІЗНИХ РОЗЧИНІВ
}

\author{
СН. І. Гудзь \\ Львівський національний медичний університет імені Данила Галицького
}

\begin{abstract}
Резюме: на початкових етапах фрармацевтичної розробки використовують лабораторні серії для апробації запропонованого складу та методик контролю якості, вивчення технологічних особливостей лікарського засобу, впливу допоміжних речовин на його фрізико-хімічні характеристики тощо. Виконання методик монографії Європейської фрармакопеї на «Розчини для перитонеального діалізу» не завжди можливе на початкових етапах у зв'язку з недоступністю в місці розробки дорогого аналітичного обладнання чи реактивів. Розроблено методику прямого спектрофротометричного визначення 5-гідроксиметилфурфруролу як основного продукту дегідратації глюкози на основі показника питомого світлопоглинання у розчинах для перитонеального діалізу. Ця методика дає можливість на ранніх етапах фрармацевтичної розробки оцінювати вплив рН, концентрації глюкози, натрію лактату і режиму стерилізації на ступінь деградації глюкози в перитонеальних діалізних розчинах. Прямий аргентометричний метод дає можливість швидко визначити вміст хлорид-іонів та встановити взаємозв'язок між кількістю стабілізатора, рН та вмістом хлорид-іонів.
\end{abstract}

Ключові слова: перитонеальний діаліз, аргентометрія, 5-гідроксиметилфурфурол.

Вступ. На початкових етапах фрармацевтичної розробки використовують лабораторні серії для апробації запропонованого складу та методик контролю якості, вивчення технологічних особливостей лікарського засобу (ЛЗ), впливу допоміжних речовин на його орізико-хімічні характеристики (рН, колірність тощо). Лабораторні серії переважно невеликого об'єму - відповідно до Настанови 42-3.5:2004 їх об'єм становить 1/100-1/1000 об'єму майбутньої промислової серії $[7,8]$. Перитонеальні діалізні розчини (ПДР) належать до багатокомпонентних Л3, які, з позицій фрармацевтичної технології, містять несумісну композицію: глюкозу й натрію лактат. У присутності останнього глюкоза піддається деградації, ступінь якої залежить насамперед від рН, концентрації натрію лактату і глюкози моногідрату. Попередні дослідження з розробки ПДР свідчать про те, що особливістю їх складу та технології $€$ підбір кількостей хлористоводневої кислоти для досягнення оптимального значення рН до стерилізації для мінімізації утворення продуктів деградації глюкози (ПДГ) під час стерилізації, вивчення впливу режиму стерилізації на утворення ПДГ [1-5].

Виконання фрармакопейних методик монографрії Європейської фрармакопеї на «Розчини для перитонеального діалізу» не завжди можливе на початкових етапах у зв'язку з недоступністю в місці розробки дорогого аналітичного обладнання чи реактивів [17].

Тому метою даного дослідження є опрацювання доступних методик контролю для розробки лабораторної технології розчинів для перитонеального діалізу (ПД).
Методи дослідження. У роботі використовували методи аналізу, узагальнення, систематизації, порівняння, аргентометричний, інструментальні (потенціометричний, спектрофоотометричний). Ці методи використовували для систематизації даних технологічних та аналітичних експериментів, а також висновків про вплив $\mathrm{pH}$ на стабільність об'єктів дослідження. Аргентометричний метод використовували для кількісного визначення хлоридів у ПдР. Інструментальні методи аналізу використовували для вимірювання $\mathrm{pH}$ розчинів до і після стерилізації, а також для знімання спектрів поглинання в ультрафріолетовій і видимій ділянці спектра, визначення максимумів поглинання, значення оптичної густини в максимумах поглинання і при певних довжинах хвиль. Процес деградації глюкози оцінювали за зміною значення рН після стерилізації та за значеннями оптичної густини при довжинах хвиль 228-230 нм і в діапазоні 278-286 нм.

Спектрофотометричні дослідження розчинів до i після стерилізації проводили на спектрофотометрах «Cary 50» та «Cary 100» виробництва фрірми «Varian» (США), а також «Lambda 20» виробництва фрірми «Perkin Elmer» (США) i «Specord 210 Plus». Спектри поглинання розчинів без розведення вимірювали в інтервалі довжин хвиль 220-500 нм з використанням кювети 3 товщиною шару 1 см. Як компенсаційний розчин використовували воду очищену. Значення $\mathrm{pH}$ випробовуваних розчинів (без розведення) до і після стерилізації вимірювали на рН-метрах «MP-220» (Швейцарія), «рН-150 M» (Білорусь), «Sartorius AG» (Німеччина) при одній і тій же температурі в інтервалі від $20{ }^{\circ} \mathrm{C}$ до $25^{\circ} \mathrm{C}$. Перед вимірюваннями рН-метри

ISSN 2312-0967. Pharmaceutical review. 2015. № 2 
Фармацевтична технологія, біофармація, гомеопатія Pharmaceutical technology, biopharmacy, homeopathy

калібрували за допомогою буферного розчину з $\mathrm{pH}$ 4,01 і одного-двох буферних розчинів зі значеннями pH 6,87; 7,0; 9,18; 10,01. Електроди занурювали у випробуваний розчин і вимірювали рН в тих же умовах, що і для бусерних розчинів.

Результати й обговорення. Хлорид-іони $€$ одним 3 ключових компонентів ПДР, знання кількісного вмісту про які дає можливість припустити про вміст натрію хлориду як основного хлоридовмісного компоненту в розчині на стадії його виготовлення. Європейська фрармакопея для кількісного визначення хлорид-іонів у розчинах для ПД пропонує метод Фольгарда. Ця методика вимагає наявності двох титрованих розчинів (аргентум нітрату і амоній тіоціанату) та розчинника дибутилорталату, який покриває осад аргентум хлориду і захищає його від контакту 3 розчином [17]. Таким чином, виконання цієї методики на початкових стадіях розробки ЛЗ є трудомістким та часозатратним.

Для кількісного визначення хлорид-іонів та вивчення впливу хлористоводневої кислоти на їх вміст запропоновано методику прямого аргентометричного методу. Першочерговими завданнями при розробці цієї методики було підібрати об'єм проби для аналізу, розрахувати об'єм індикатора, який необхідний для чіткої зміни забарвлення, та оцінити її придатність для рутинного аналізу та потенційної валідації.

У прямому аргентометричному методі індикатор калію хромат у точці кінця титрування утворює осад аргентум хромату, який забарвлений в оранжевий колір [9]. Знаючи добуток розчинності арґентум хлориду $\left(Д \mathrm{P}_{\mathrm{AgCl}}=1,2 \cdot 10^{-10}\right.$ моль $^{2}$ дм$\left.^{-6}\right)$, можна розрахувати концентрацію іонів аргентуму в точці еквівалентності: $\left[\mathrm{Ag}^{+}\right]=1,1 \cdot 10^{-5}$ моль.дм ${ }^{-3}$. Концентрацію хромат-іонів, необхідних для осадження іонів аргентуму зазначеної концентрації, можна знайти зі значення добутку розчинності аргентуму хромату:

$\left[\mathrm{Ag}^{+}\right]^{2} \cdot\left[\mathrm{CrO}_{4}{ }^{2-}\right]=2,4 \cdot 10^{-12}$ моль $^{3}$. дм ${ }^{-9} ;$ звідси $\left[\mathrm{CrO}_{4}{ }^{2-}\right]=$ $2,1 \cdot 10^{-2}$ моль . дм ${ }^{-3}$.

Знаючи цю концентрацію, можна обчислити об'єм індикатора, який необхідно додати до проби для титрування [10]. Для отримання 10 мл розчину (об'єм проби, яка титрується) 3 концентрацією хромат-іонів 2,1.10-2 моль· дм $^{-3}$ потрібно до початку титрування додати в пробу 0,8 мл 5 \% розчину хромату калію. Відповідно, для отримання 5 мл проби з такою ж концентрацією хромат-іонів потрібно до початку титрування додати 0,4 мл розчину індикатора.

Методика прямого аргентометричного методу апробовувалась на кількох лабораторних серіях розчинів для ПД різного складу, в тому числі за вмістом хлорид-іонів. Взаємозв'язок між рН розчину, кількістю доданого 1 М розчину хлористоводневої кислоти, об'ємом проби та кількісним вмістом хлорид-іонів наведено у таблиці 1. Як свідчать дані таблиці 1, додавання 1 М розчину хлористоводневої кислоти до 1 л розчину суттєво впливає на рН розчину та незначно впливає на вміст хлорид-іонів. У серії 20415 спостерігаються незначні зміни вмісту хлорид-іонів після стерилізації. Однак такі зміни (0,1 \% - 0,5 \%) вважаються

Таблиця 1. Взаємозв'язок між рН розчину, кількістю доданого 1 М розчину хлористоводневої кислоти і кількісним вмістом хлорид-іонів для розчинів з вмістом глюкози моногідрату 2,5 \%

\begin{tabular}{|c|c|c|c|c|c|c|c|c|}
\hline \multicolumn{4}{|c|}{$\begin{array}{c}\text { Серія 10112*, номінальний вміст хлорид-іонів } \\
103,5 \text { ммоль/л (100 \%), об'єм проби } 5 \text { мл }\end{array}$} & \multicolumn{5}{|c|}{$\begin{array}{l}\text { Серія } 20415^{\star *}, \text { номінальний вміст хлорид-іонів } 100 \text { ммоль/л } \\
\text { (100\%), об'єм проби } 10 \text { мл }\end{array}$} \\
\hline \multicolumn{2}{|c|}{$\mathrm{pH}$} & \multirow{3}{*}{$\begin{array}{c}\text { Об'єм } \\
\text { доданого } \\
1 \mathrm{M} \\
\text { р-ну НСl }\end{array}$} & \multirow{3}{*}{$\begin{array}{c}\text { Кількісний } \\
\text { вміст } \\
\text { хлорид- } \\
\text { іонів після } \\
\text { стери- } \\
\text { лізації, } \\
\text { ммоль/л } \\
\end{array}$} & \multicolumn{2}{|r|}{$\mathrm{pH}$} & \multirow{3}{*}{$\begin{array}{c}\text { Об'єм } \\
\text { доданого } \\
1 \mathrm{M} \\
\text { р-ну НСl } \\
\text { на } 1 \text { л } \\
\text { розчину }\end{array}$} & \multirow{2}{*}{\multicolumn{2}{|c|}{$\begin{array}{l}\text { Кількісний вміст хлорид- } \\
\text { іонів, ммоль/л }\end{array}$}} \\
\hline & & & & \multirow[b]{2}{*}{$\begin{array}{c}\text { до } \\
\text { стери- } \\
\text { лізації }\end{array}$} & \multirow[b]{2}{*}{$\begin{array}{c}\text { після } \\
\text { стерилізації, } \\
\text { зміна рH }\end{array}$} & & & \\
\hline $\begin{array}{c}\text { до } \\
\text { стери- } \\
\text { лізації }\end{array}$ & $\begin{array}{l}\text { стерилі- } \\
\text { зації, } \\
\text { зміна рН }\end{array}$ & & & & & & $\begin{array}{c}\text { до } \\
\text { стерилізації }\end{array}$ & $\begin{array}{c}\text { після } \\
\text { стерилізаціі }\end{array}$ \\
\hline 6,48 & 5,$99 ; 0,49$ & 0 & 102,1 & 6,44 & 5,$72 ; 0,72$ & 0 & 98,99 & 99,24 \\
\hline 6,28 & 6,$02 ; 0,26$ & 0,2 & 103,2 & & & & & \\
\hline 6,17 & 5,$86 ; 0,31$ & 0,4 & 103,8 & 6,05 & 5,$65 ; 0,40$ & 0,2 & 99,29 & 99,19 \\
\hline 5,74 & 5,$66 ; 0,08$ & 0,6 & 103,2 & 5,72 & 5,$57 ; 0,15$ & 0,49 & 99,59 & 99,49 \\
\hline 5,35 & 5,$33 ; 0,02$ & 1,2 & 103,5 & 5,42 & 5,$39 ; 0,03$ & 1,0 & 100,29 & 99,79 \\
\hline \multirow{2}{*}{\multicolumn{2}{|c|}{$\begin{array}{l}\text { Різниця вмісту } \\
\text { хлорид-іонів }{ }^{\star \star \star ~}\end{array}$}} & & & 5,21 & 5,$21 ; 0$ & 1,6 & 100,64 & 100,54 \\
\hline & & $\Delta=1,2$ мл & $\begin{array}{l}\Delta=1,1-1,7 \\
\text { ммоль/л } \\
(1,1-1,7 \%)\end{array}$ & & & $\Delta=1,6$ мл & $\begin{array}{l}\Delta=0,3-1,65 \\
\text { ммоль/л } \\
(0,3-1,65 \%)\end{array}$ & $\begin{array}{l}\Delta=-0,05-1,3 \\
\text { ммоль/л } \\
(0,05-1,3 \%)\end{array}$ \\
\hline
\end{tabular}

Примітки: * - склад: іони в ммоль/л: натрію 134, кальцію 1,75, магнію 0,5, хлорид 103,5, лактат 35; глюкози моногідрат 2,5\%;

** - склад: іони в ммоль/л: натрію 132, кальцію 1,25, магнію 0,25, хлорид 100, лактат 35; глюкози моногідрат 2,5 \%;

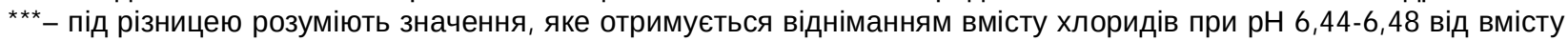
хлорид-іонів при інших значеннях рН.

ISSN 2312-0967. Фармацевтичний часопис. 2015. № 2 
незначущими відповідно до принципу незначущості, оскільки виконується умова $\Delta \leq 0,32 \cdot \Delta_{\mathrm{As}} \leq 0,32 \cdot 1,6 \leq$ $0,51 \%$, де 1,6 - повна невизначеність аналізу $\left(\Delta_{\mathrm{As}}\right)$ у відсотках, яка обчислюється наступним чином при вмісті компонента 95-105 \% від заявленого вмісту: $\Delta_{\text {As }} \leq(105 \%-95 \%): 2 \cdot 0,32 \leq 1,6 \%$ [6].

При проведенні теоретичних розрахунків встановлено, що додавання 0,2-1,6 мл 1 М розчину хлористоводневої кислоти до розчину з номінальним вмістом хлорид-йонів 100-103,5 ммоль/л збільшує вміст хлорид-іонів на 0,2-1,6 ммоль або на 0,2-1,6 \%. Експериментальні дані підтвердили, що різниця вмісту хлорид-іонів при інших значеннях $\mathrm{pH}$ та рН 6,4 практично у всіх випадках знаходилася в межах повної невизначеності аналізу $\left(\Delta_{\mathrm{As}}=1,6 \%\right)$. Проте експериментальні дані щодо визначення вмісту хлорид-іонів у серії 10112 свідчать про порушення залежності між кількістю доданої хлористоводневої кислоти та визначеним вмістом хлорид-іонів, а також про більшу різницю у вмісті хлорид-іонів порівняно з серією 20415, що пояснюється похибкою, спричиненою меншим об'ємом проби для методики (5 мл) [6].

У результаті проведених аналітичних досліджень для рутинного контролю та валідації запропонована кінцева методика у наступній редакції: 10 мл лз поміщають у конічну колбу місткістю 50 мл, додають 0,8 мл розчину калію хромату (індикатора) і титрують 0,1 М розчином аргентум нітрату до появи червонокоричневого осаду. 1 мл 0,1 М розчину срібла нітрату відповідає 3,545 мг Сl- (хлорид-іонів), яких в 1 мл Л3 повинно бути від 95 до 105 \% від заявленого складу.

Спектрофотометричне визначення 5-гідроксиметилфурфруролу (5-ГМФ) та споріднених йому сполук. Ряд зарубіжних фрармакопей нормує кількість 5-ГМФ в розчинах для парентерального застосування по-різному. Але спільним для всіх фрармакопей $є$ спектрофотометричне визначення цієї сполуки і нормування її за оптичною густиною розчину $[17,18]$. У хімічній промисловості для швидкого аналізу визначення вмісту 5-ГМФ в реакційних середовищах використовують прямий спектрофотометричний метод із використанням молярного показника поглинання, який дещо відрізняється в різних публікаціях (16600 л-моль $\left.{ }^{-1} \mathrm{CM}^{-1}, 16830,22700\right)$. Дана речовина як продукт побічного синтезу кількісно визначається в полідекстрозі відповідно до Фармакопеї США за допомогою цього показника, який становить 16830 [14, 15, 18, 19]. Тому для порівняльних досліджень впливу $\mathrm{pH}$ та різних чинників на вміст 5-ГМФ ми використо- вували значення питомого показника молярного поглинання 16830 л'моль ${ }^{-1} \cdot \mathrm{CM}^{-1}$.

Основні ПДГ (3,4-дидезоксиглюкозон-3-ен (3,4 ДГЕ) та 5-ГМФ), ми визначали методом прямої спектрофоотометрії при 228-230 і 278-286 нм, відповідно, шляхом вимірювання оптичної густини ПдР без розведення. Враховуючи те, що в розчинах для ПД вміст 5-ГМФ залежить від концентрації глюкози і не повинен перевищувати 10 мкг із розрахунку на кожні 25 мг глюкози, ми розрахували допустиму концентрацію 5-ГМФ у досліджуваних розчинах для ПД у відсотках: $\mathrm{C}=0,544 \cdot 10^{-3} \%$ при вмісті глюкози моногідрату 1,5\%; $0,920 \cdot 10^{-3} \%-2,5 \% ; 1,560 \cdot 10^{-3} \%-4,25 \%$.

Знаючи допустиму концентрацію 5-ГМФ і значення його питомого показника поглинання, ми розрахувували допустиму оптичну густину глюкозовмісних розчинів для ПД. Результати залежності допустимого значення абсорбції розчину для ПД від вмісту глюкози моногідрату представлені представлені в таблиці 2.

Як свідчать експериментальні дані, представлені в таблиці 3, найбільша зміна рН відбувається у розчинах, які мали рН до стерилізації 6,05-6,64. Різниця рН відповідно становить 0,40-1,33 і залежить від концентрації глюкози моногідрату та натрію лактату, $\mathrm{pH}$ розчину до стерилізації й режиму стерилізації. Зменшення рН розчинів вказує на термодеструкцію глюкози з утворенням низькомолекулярних органічних кислот: левулінова, мурашина, 5-гідроксиметилфуранкарбонова та інші [11, 12, 14]. Однак зменшення різниці $\mathrm{pH}$ в розчинах $3 \mathrm{pH}$ від 6,44 до 5,21 не дає підстави стверджувати про зменшення ступеня деградації глюкози, оскільки в міру додавання хлористоводневої кислоти зростає бусрерна ємність системи лактат натрію - молочна кислота, яка протидіє зміні рН системи. Згідно з літературними даними, буферна ємність тим вища, чим більші концентрації компонентів буферної системи і чим менші ці концентрації відрізняються між собою [13]. У міру додавання хлористоводневої кислоти концентрація молочної кислоти наростає, що сприяє зближенню концентрацій натрію лактату і молочної кислоти в системі. Зміна $\mathrm{pH}$ у розчинах повністю узгоджується $з$ попередніми дослідженнями, представленими у публікаціях $[1,2,3,4]$. УФ-спектри до стерилізації свідчать про відсутність ПДГ до стерилізації та підтверджують утворення 3,4-ДГЕ (збільшення оптичної густини при 228-230 нм), 5-ГМФ і споріднених сполук (збільшення оптичної густини

Таблиця 2. Взаємозв'язок допустимого значення абсорбції розчинів від вмісту глюкози моногідрату

\begin{tabular}{|c|c|c|}
\hline $\begin{array}{c}\text { Вміст глюкози моногідрату, } \\
\text { (глюкози безводної), \% }\end{array}$ & Допустимий вміст 5-гМФ, \% & $\begin{array}{c}\text { Допустиме значения оптичної } \\
\text { густини (A) }\end{array}$ \\
\hline $1,5(1,36)$ & $0,544 \cdot 10^{-3}$ & 0,727 \\
\hline $2,5(2,3)$ & $0,920 \cdot 10^{-3}$ & 1,229 \\
\hline $4,25(3,9)$ & $1,560 \cdot 10^{-3}$ & 2,084 \\
\hline
\end{tabular}

ISSN 2312-0967. Pharmaceutical review. 2015. № 2 
Фармацевтична технологія, біофармація, гомеопатія Pharmaceutical technology, biopharmacy, homeopathy

при 274-283 нм) у всіх серіях після стерилізації. Згідно 3 літературними даними, для 5-ГМФ характерний максимум поглинання від 278 до 286 нм, для 3,4ДГЕ 228-230 нм $[11,16]$. Як свідчать експериментальні дані, положення максимуму залежить від рH розчину: чим менше значення $\mathrm{pH}$, тим положення максимуму зміщено вправо. Однак при рН 6,05-6,21 спостерігається незначне зменшення довжини хвилі в максимумі (1-2 нм), що очевидно пояснюється дещо іншим механізмом утворення 5-ГМФ саме в цьому діапазоні рН. При зростанні рН від 5,2 до 6,6 оптична густина в діапазоні 228-230 нм поступово наростає, що узгоджується 3 літературними даними: при рН вище 3,5 домінує процес деградації до
3,4-ДГЕ [16], а також власними експериментальними дослідженнями [2, 3]. Однак при зростанні рН від 5,2 до 6,6 абсорбція в максимумі поглинання також поступово наростає. Незначне відхилення від даної залежності спостерігається для серії 20415.

Розроблена методика прямого спектрофотометричного методу кількісного визначення Пдг дала можливість оцінити вплив режиму стерилізації на їх концентрацію у серіях 20413 і 40513. Збільшення часу нагрівання до досягнення температури стерилізації в серії 40513 не значно відобразилося на зміні $\mathrm{pH}$, однак суттєво відобразилося на значеннях оптичних густин за довжин хвиль 228-230 нм і абсорбції в максимумі поглинання.

Таблиця 3. Фізико-хімічні показники розчинів для перитонеального діалізу з різним вмістом натрію лактату й глюкози моногідрату

\begin{tabular}{|c|c|c|c|c|c|c|}
\hline \multicolumn{2}{|c|}{$\mathrm{pH}$} & \multirow[b]{3}{*}{$\Delta \mathrm{pH}$} & \multicolumn{4}{|c|}{ Оптична густина розчину } \\
\hline \multirow[b]{2}{*}{$\begin{array}{c}\text { до } \\
\text { стерилі- } \\
\text { зації }\end{array}$} & \multirow[b]{2}{*}{$\begin{array}{c}\text { після } \\
\text { стерилізації }\end{array}$} & & \multicolumn{2}{|c|}{ до стерилізації } & \multicolumn{2}{|c|}{ після стерилізації } \\
\hline & & & за $\lambda 228 \mathrm{Hм}$ & за $\lambda 284 \mathrm{Hм}$ & за $\lambda$ 228-230 нм & $\begin{array}{c}\text { у } \lambda_{\max } \text { (не більше 2,084 } \\
\text { для 20413, 40513; } \\
1,229 \text { для 10415); } \\
\text { максимум поглинання }\end{array}$ \\
\hline
\end{tabular}

серія 20413, склад іони в ммоль/л: натрію 132, кальцію 1,25, магнію 0,25, хлорид 95, лактат 40; глюкози моногідрат 4,25 \%

\begin{tabular}{|l|l|l|l|l|l|l|}
\hline 6,54 & 5,48 & 1,06 & 0,3046 & 0,0236 & $1,509-1,390$ & $0,854(275$ нм $)$ \\
\hline 6,12 & 5,50 & 0,62 & 0,2839 & 0,0144 & $1,375-1,261$ & $0,706(274$ нм $)$ \\
\hline 5,73 & 5,43 & 0,3 & 0,3351 & 0,0339 & $1,283-1,172$ & $0,621(275$ нм $)$ \\
\hline 5,42 & 5,3 & 0,12 & 0,3402 & 0,0326 & $1,147-1,042$ & $0,541(278$ нм $)$ \\
\hline 5,24 & 5,24 & 0 & 0,3306 & 0,0250 & $0,354-0,268$ & $\begin{array}{c}\text { максимум не виявлений } \\
0,040-0,036 \text { в діапазоні } \\
278-286 \text { нм }\end{array}$ \\
\hline
\end{tabular}

серія 40513, склад: іони в ммоль/л: натрію 132, кальцію 1,25, магнію 0,25, хлорид 95, лактат 40; глюкози моногідрат 4,25\%

\begin{tabular}{|l|l|l|l|l|l|c|}
\hline 6,64 & 5,31 & 1,33 & $0,267-0,186$ & $\begin{array}{l}0,016- \\
0,014\end{array}$ & $3,107-2,947$ & $2,335(278 \mathrm{HM})$ \\
\hline 6,20 & 5,36 & 0,84 & $0,270-0,189$ & $\begin{array}{l}0,02 \\
0,016\end{array}$ & $2,628-2,484$ & $1,662(277 \mathrm{HM})$ \\
\hline 5,68 & 5,31 & 0,37 & $0,283-0,200$ & $\begin{array}{l}0,018- \\
0,015\end{array}$ & $2,465-2,327$ & $1,621(278 \mathrm{HM})$ \\
\hline 5,43 & 5,25 & 0,18 & $0,295-0,211$ & $\begin{array}{l}0,022- \\
0,020\end{array}$ & $2,194-2,066$ & $1,357(280 \mathrm{HM})$ \\
\hline 5,20 & 5,15 & 0,05 & $0,317-0,229$ & 0,043 & $1,995-1,872$ & $1,282(281 \mathrm{HM})$ \\
\hline
\end{tabular}

серія 20415, склад іони в ммоль/л: натрію 132, кальцію 1,25, магнію 0,25, хлорид 100, лактат 35; глюкози моногідрат 2,5

\begin{tabular}{|l|l|l|l|l|l|l|}
\hline 6,44 & 5,72 & 0,72 & $0,253-0,174$ & $\begin{array}{l}0,0079- \\
0,0082\end{array}$ & $1,4280-1,3240$ & $0,565(278 \mathrm{HM})$ \\
\hline 6,05 & 5,65 & 0,40 & $0,259-0,179$ & $\begin{array}{l}0,0078- \\
0,0083\end{array}$ & $1,4216-1,3191$ & $0,527(276 \mathrm{HM})$ \\
\hline 5,72 & 5,57 & 0,15 & $0,258-0,178$ & $\begin{array}{l}0,0068- \\
0,0069\end{array}$ & $1,2489-1,1516$ & $0,385(278 \mathrm{HM})$ \\
\hline 5,42 & 5,39 & 0,03 & $0,263-0,181$ & $\begin{array}{l}0,0024- \\
0,0029\end{array}$ & $1,1899-1,0953$ & $0,382(281 \mathrm{HM})$ \\
\hline 5,21 & 5,21 & 0 & $0,272-0,189$ & $\begin{array}{l}0,0039- \\
0,0046\end{array}$ & $1,1394-1,0445$ & $0,418(283 \mathrm{HM})$ \\
\hline
\end{tabular}

ISSN 2312-0967. Фармацевтичний часопис. 2015. № 2 
Висновки. Розроблена методика спектрофотометричного визначення 5-ГМФ, як основного ПДГ, у розчинах для ПД на основі показника питомого молярного світлопоглинання дає можливість на ранніх етапах фрармацевтичної розробки оціню- вати вплив рН, концентрації глюкози, натрію лактату і режиму стерилізації на ступінь деградації глюкози в ПДР. Прямий аргентометричний метод дає можливість швидко визначити вміст хлоридіонів.

\section{Література}

1. Гудзь Н. І. Дослідження залежності фрізико-хімічних властивостей глюкозолактатногідрокарбонатних перитонеальних діалізних розчинів від концентрації натрію лактату та натрію гідрокарбонату / Н. І. Гудзь // Фармацевтичний журнал. - 2008. - № 5. - С. 71-76.

2. Гудзь Н. І. Вивчення фрізико-хімічних властивостей глюкозогідрокарбонатних перитонеальних діалізних розчинів / Н. І. Гудзь // Фармацевтичний журнал. - 2008. - № 6. - С. 68-74.

3. Гудзь Н. І. Стабільність глюкозоелектролітних розчинів 3 вмістом глюкози 1,5 \% і 4,25 \% / Н. І. Гудзь // Актуальні питання фрармацевтичної і медичної науки та практики. - 2011. Випуск XXIV. - С. 85-86.

4. Гудзь Н.І.Визначальні чинники у розкладі глюкози в лактатних розчинах для перитонеального діалізу / Н. І. Гудзь // Науково-технічний прогрес і оптимізація технологічнихпроцесів створення лікарськихпрепаратів: матер. наук.-практ. конференція з міжнародною участю, Тернопіль, 27-28 вересня 2013 р. - Тернопіль, 2013. C. $94-98$.

5. Гудзь Н. І. Обгрунтування показників якості та їх критеріїв прийнятності для розчинів, які застосовуються в замісній нирковій терапії / Н. І. Гудзь // Збірник наукових праць співробітників НМАПО ім. П. Л. Шупика - 2013. Вип.22 (4). - С. 376-384.

6. Державна фрармакопея України. Доповнення $2 /$ Харьків: Державне підприємство «Науково-експертний фрармакопейный центр», 2004. - 672 с.

7. Настанова 42-3.1:2004 «Настанови з якості. Лікарські засоби. Фармацевтична розробка» / М. Ляпунов, В. Георгієвський, О. Безугла [та ін.] - Київ, МОЗ України, 2004. - 15 c.

8. Настанова 42-3.5:2004. Настанови з якості. Лікарські засоби. Валідація процесів. - Київ, 2004. - 24 с.

9. Основы аналитической химии: В 2 кн. Кн. 2. Методы химического анализа / под ред. Ю. А. Золотова. - 2-е изд., перераб. и доп. - М. : Высшая школа, 1999. $494 \mathrm{c}$.

10. Рэмстен Э. Н. Начала современной химии: справ. изд. ; пер с англ. ; под ред. В. И. Барановского,

А. А. Белюстина, А. И. Ефримова, А. А. Потехина - Л. : Химия, 1989. -784 с.

11. Терешкина О. И. Исследование продуктов термодеструкции глюкозы в модельных растворах / О. И. Терешкина, И. В. Исаева // Фармация. - 1991. № 6. - C. 24-28.

12. Терешкина О. И. Новые аспекты контроля и стандартизации растворов глюкозы для инъеций: авторефр. дис. ... канд. фрарм. наук: 15.00.02 / Моск. мед. акад. им. И. М. Сеченова. - М., 1990. - 24 с.

13. Физическая и коллоидная химия : учеб. для фрарм. вузов и фракультетов / под ред. К. И. Евстратовой. - М. : Высш. шк., 1990. - 487 с.

14. Черняк М. Ю. Кислотно-каталитические превращения углеводов в присутствии спиртов при умеренных температурах // Дис. на соискание ученой степени канд. хим. наук // Красноярск, 2013. - Режим доступу: http://chemfiles.narod.ru/met_ka/dissert.pdf

15. Biopolymer templated porous $\mathrm{TiO}_{2}$ : An efficient catalyst for the conversion of unitilized sugars derived from hemicelluloses / Sudipta De, Saikat Dutta, Astam K. Patra [et al.] // Applied Catalylis A: General. - 2012. - P.197203. Режим доступу: http://www.academia.edu/2473566/ Biopolymer_templated_Porous_TiO2_An_Efficient_ Catalyst_for_the_Conversion_of_Unutilized_Sugars_Derived_from_Hemicellulose

16. Erixon M. How to avoid glucose degradation products in peritoneal dialysis fluids / M. Erixon // Perit. Dial. Int. 2006. - №4. - P. 490-497. - Access mode: http://www. ncbi.nlm.nih.gov/pubmed/16881345.

17. European Pharmacopeia 8.0 Режим доступу: http:// online.edqm.eu/EN/entry.htm

18. Polydextrose. Режим доступу: http://www.drugfuture. com/Pharmacopoeia/usp35/PDF/1896-1898\%20 Polydextrose.pdf

19. Rapid Method for the Determination of 5-Hydroxymethylfurfural and Levulinic Acid Using a DoubleWavelenght UV Spectroscopy / Junhua Zhang, Junke $\mathrm{Li}$, Yanjun Tang, and Guoxin Xue // The scientific World Journal. - 2013, article ID 506329. Режим доступу: http:// dx.doi.org/10.1155/2013/506329 
Фармацевтична технологія, біофармація, гомеопатія

Pharmaceutical technology, biopharmacy, homeopathy

РАЗРАБОТКА МЕТОДИК КОНТРОЛЯ ДЛЯ ЛАБОРАТОРНОЙ ТЕХНОЛОГИИ

ГЛЮКОЗОСОДЕРЖАЩИХ ПЕРИТОНЕАЛЬНЫХ ДИАЛИЗНЫХ РАСТВОРОВ

\author{
Н. И. Гудзь \\ Львовский национальный медицинский университет имени Данила Галицкого
}

Резюме: на начальных этапах фрармацевтической разработки используются лабораторные серии для апробации предложенного состава и методик контроля качества, изучение технологических особенностей лекарственного средства, влияния вспомогательныхвеществ наего физико-химическиехарактеристикиитомуподобное. Выполнение методик монографии Европейской фрармакопеи на «Растворы для перитонеального диализа» не всегда возможно на начальных этапах в связи с недоступностью в месте разработки дорогостоящего аналитического оборудования или реактивов. Разработана методика прямого спектрофотометрического определения 5-гидроксиметилфурфурола как основного продукта дегидратации глюкозы на основе показателя удельного светопоглощения в растворах для перитонеального диализа. Эта методика дает возможность на ранних этапах фрармацевтической разработки оценивать влияние $\mathrm{pH}$, концентрации глюкозы, натрия лактата и режима стерилизации на степень деградации глюкозы в перитонеальных диализных растворах. Прямой аргентометричний метод дает возможность быстро определить содержание хлорид-ионов и установить взаимосвязь между количеством стабилизатора, рН и содержанием хлорид-ионов.

Ключевые слова: перитонеальный диализ, аргентометрия, 5-гидроксиметилфурфурол.

\title{
DEVELOPMENT OF ANALITICAL PROCEDURES OF QUALITY CONTROL FOR LABOLATORY BACHES OF DEXTROSE CONTAINING SOLUTIONS FOR PERITONEAL DIALYSIS
}

\author{
N. I. Hudz \\ Lviv National Medical University by Danylo Halytsky
}

Summary: laboratory batches are used in the initial stages of pharmaceutical development for the purpose of testing the proposed composition, techniques of quality control, studying features of a medicinal product, excipients impact on its physical and chemical characteristics etc. Implementation methods of pharmacopoeia monographs of the European Pharmacopoeia for "Solutions for peritoneal dialysis" may be imposible in early stages due to unavailability of expensive analytical equipment or reagents at the site of the development. 5-hydroxymethylfurfural is a product of irreversible dextrose dehydratation. The method of direct spectrophotometric determination of 5-hydroxymethylfurfural is offered for dextrose containing solutions for peritoneal dialysis. Its concentarion is calculated on the basis of molar absorption coefficient $\left(16830 \mathrm{~L} \cdot \mathrm{mol}^{-1} \cdot \mathrm{cm}^{-1}\right)$. This technique enables in the early stages of pharmaceutical development to assess the effect of $\mathrm{pH}$, dextrose, sodium lactate and sterilization on the degree of degradation of dextrose in solutions for peritoneal dialysis. Direct argentometric method makes possible to identify quickly the content of chloride ions and establish the relationship between the amount of hydrochloric acid as stabilizer, $\mathrm{pH}$, and content of chloride ions.

Key words: peritoneal dialysis, argentometry, 5-hydroxymethylfurfural.

Отримано 27.04.2015

ISSN 2312-0967. Фармацевтичний часопис. 2015. № 2 